第18回日本臨床麻酔学会総会シンポジウム

\title{
小児麻酔の現況 前投薬・術前管理
}

前川信博* 仁科かほる* 三川勝也* 尾原秀史*

\section{I はじめに}

"One is not just anesthetizing the child, one is really anesthetizing the family”といわれるように, 安全で円滑な麻酔の導入・管理には, 患児だけでな く親も含めた「家族」に対するよりよい術前管理が 前提になるのはいうまでもないが，他分野における 進歩や社会的背景の変化によって, 小児麻酔領域に おいても「考え方の切り換え」を必要とする項目が いくつか出てきている(表1)。それらのうち, 本稿 では「日々の麻酔を再検討する」という本学会のテ ーマに従って, 術前管理に関係した上気道感染, 喘 息，前投薬，絶飲水の四つの項目を取り上げる.

\section{II 上気道感染 (URI)}

上気道感染 (URI) に罹っている子どもに麻酔を行 なうと, 急性期であれ回復期であれ, 合併症は増加 する，例えば，術中の低 $\mathrm{SpO}_{2}$ の頻度は増加するし， 喉頭痙攣や気管支痓攣の頻度もそれぞれ 5 倍, 10 倍 と増加するといわれている. 炎症による気道粘膜の 過敏性の消失には 6 ～週かかるが, 麻酔をそれだ け長期間延期することは社会的な制約から実際的で はない．通常は大多数の麻酔科医は 2 週間程延期す ることにしているようである。

\section{III 喘 息}

周術期における喘息発作の頻度は喘息既往がある

*神戸大学医学部麻酔学教室
場合は約 $10 \%$ といわれている. 特に, 最終発作が 2 週間以内の場合には約 $30 \%$ と特に高頻度であるた め，緊急手術以外はこの期間を避けるのが賢明と思 われる.

麻酔管理は, (1)発作予防の処置と(2)発作時の処置 の二つに分けて考えるのが合理的である。その際, 「喘息発作には気道粘膜における炎症の存在が重要 である」という考えに基づいた管理が大切になる。

喘息発作の予防・寛解にわれわれが利用できる薬 物としては，(1)テオフィリン製剤(経口，静注)，(2) ステロイド(吸入, 経口, 静注), (3) $\beta$-刺激薬(吸入, 皮下注, 筋注, 静注), (4)リドカイン(静注) 等, 種々あるが, 挿管操作等の刺激が加わるときに, 十 分すぎるぐらいの麻酔深度であることが最も重要な 発作予防法である.

\section{1. テオフィリン, アミノフィリン}

(1)発作に対し，カテコラミンとの併用ではテオフィ リン自身の効果は認めなかった，(2)ヒスタミンで誘 発した気管支㾏攣を改善しなかった(イヌの実験), (3)発作の寛解にアミノフィリンはあまり有効でない (臨床経験) 等より, テオフィリンの役割は, (1)喘息 患者の発作予防のbaseの薬物としての使用, (2) COLD 患者の喀痰排泄の促進・横隔膜筋力の増強, にあると考えられている。

術前処置 : すでに内服しているなら続け, 未使用 なら術前 1 週間より処方する.

\section{2. ステロイド(吸入, 経口, 静注)}

(1)発作予防には最も有効 (気道粘膜の炎症状態存 在は発作を誘発しやすくする), (2)吸入や静注ステ 
表 1 小児麻酔領域において見直しや検討の必要な項目
- 術前検査

·糖質添加

·貧血

·術後無呼吸発作

·上気道感染

・痛み

·喘息

·悪心/ 嘔吐

\section{·絶飲水}

ロイドの効果発現はかなり早い(投与後 $2 \sim 3$ 時間以 内）ため，前投薬としても使用可能なこと等が特徵 である。

術前処置：喘鳴を聴取したりステロイド吸入の既 往がある場合は必須．常用しているなら続け，未使 用なら術前 1 週間より開始する(例：アルデシンやべ コタイドを $2 \sim 3$ 回/日吸入.ふいごのようなスペー サーを用いるとうまく吸入できる)。

\section{3. $\beta$-刺激薬 (カテコラミン：皮下注, 筋注, 静注)}

発作の寛解には非常に有効であるが，循環系への 影響も強いのが欠点である．降圧薬としては，平滑 筋弛緩作用もある $\mathrm{Ca}^{2+}$ チャネル遮断薬で対処する。 頻脈と高血圧を伴うときにはジルチアゼム(ヘルベ ッサー $\left.{ }^{\circledR}\right) を ，$ 高血圧のみを伴うときにはニカルジピ ン (ペルジピン® ${ }^{\circledR}$ を用いている.

半減期が短いため, 発作が再発する場合がある. このときは持続静注を考慮する。

術前処置としては通常は用いない.

\section{4. $\beta$-刺激薬 (カテコラミン：吸入)}

発作の予防・寬解に非常に有効である，麻酔回路 への投与にはバッグや蛇管内へ定量噴霧式吸入器に よる $8 \sim 10$ 回の噴霧を行なう (回数が少ないと効果 がない)。麻酔回路へ簡単に接続して吸入薬を投与 できる専用の容器 (例：エアロチャンバー ${ }^{\circledR}$ )を手術 室に常備しておくとよい.

術前処置：常用しているなら続け，未使用なら術 前 1 週間前より開始する(例：メプチンエアーを 3 回/ 日吸入)。
表2 喘息児に対する処置のまとめ

術前処置

·ステロイドの吸入：麻酔開始 2 - 3 時間前

- $\beta$ - 刺激薬の吸入：麻酔開始 1 時間前（常用している場合）

・アトロピンの投与 : 麻酔開始 1 時間前

定量噴射式吸入器による

イプラトロピウム（アトロベント）の吸入 （前投薬としては投与しない）

麻酔開始後 (挿管操作などの刺激を加える前) や抜管前

・リドカインの静注

·ステロイドの回路内への投与

を組み合わせる

$\cdot \beta$ - 刺激薬の回路内への投与

\section{5. 処置のまとめ}

喘息児に対する処置のまとめを表 2 に示す。

\section{IV 前投薬}

硫酸アトロピンのようなベラドンナ薬は, 特別な 症例以外は麻酔導入時に静注するようになってきて いる.

鎮静薬に関しては，現在使用されている鎮静薬の すべてが約 70〜 80\%しか有効でなく，20〜 30\%も の例において不十分であるという事実を前にして， そもそもファーマコロジカルな前投薬は本当に必要 なのか？という疑問がある。一方，親の同伴によ る麻酔導入や十分な説明と理解等のサイコロジカル な前投薬の有効性についても，考えられていたほど 有効ではないという報告が発表された。この項目に 関してはまだまだ研究の余地がある．鎮静・鎮痛・ 降圧・制吐・抗ストレスといった多彩な効果を有す る $\alpha_{2}$ アゴニストであるクロニジンについては，仁 科かほるらの報告 ${ }^{1)}$ を参照していただくこととし， 本稿では省略する。一般的に経口では $4 \mu \mathrm{g} \cdot \mathrm{kg}^{-1}$, 経仙骨硬膜外では $2 \mu \mathrm{g} \cdot \mathrm{kg}^{-1}$ が用いられている。

\section{$\mathrm{V}$ 術前絶飲水 (NPO)}

麻酔の前に経口摂取を制限する必要があるが，そ 
の期間に関しては，昔と比べて著しく短縮された。 (1)短時間の NPO は誤嶼性肺障害の危険性を高めるの では.という危惧が，前夜からの絶飲水と麻酔前 $2 \sim 3$ 時間の絶飲水とでは胃液量・胃液 $\mathrm{pH}$ に関して差が なかったという多くの研究者による報告によって否 定されたことや，(2)短時間のNPOは利点として脱 水・低血糖の防止効果だけでなく, 脂質動員の抑制 や患児の精神状態を良好に保てた等の研究がその根 拠になっている。

$\mathrm{NPO}$ 期間と胃液量・ $\mathrm{pH}$ に関する現在までの研究 の要約は，(1)期間の長短にかかわらず約 $90 \%$ 览が 胃液 $\mathrm{pH} 2.5$ 以下であり, 約 $30 \sim 60 \%$ の児が $0.4 \mathrm{~m} l$ ・ $\mathrm{kg}^{-1}$ 以上の胃液量であった，(2)両者を組み合わせた いわゆるクライテリアを満たす者が約 $30 〜 60 \%$ も の高い頻度であった，となる。これは日頃の臨床に おける経験結果と著しくかけ離れている。誤嚥はそ れほど多く起こらない.

ここで, 誤嚥性肺障害について，歴史的に少し振 り返ってみる。初めて誤與をお産時の問題点として 認識したのは 1940 年の Hallであるが，1946年に Mendelsonが麻酔死に直接関係する因子として誤鮼 を取り上げた。それ以降，カフつきの気管チューブ, Selick 法 (1962)，制酸薬 (1966) や $\mathrm{H}_{2}$ ブロッカー (1981，1985，1987）等のさまざまな誤嶼防止対策が 行なわれたため, 誤嚥性肺炎=メンデルソン症候群 という“名誉”を獲得した。

さて，誤嚥による肺障害の危険性を判定するとき の「胃液量 $0.4 \mathrm{~m} l \cdot \mathrm{kg}^{-1}$ 以上・胃液 $\mathrm{pH} 2.5$ 以下」とい うクライテリアは，1974年に Roberts らが “帝王切 開時の誤嚥性肺炎のリスクの軽減”という論文で述 ベたサルを用いた「未発表」データを, その後の研 究者が無比判に引用し続けたためにスタンダードク
ライテリアになったと思われる，誤嚥による肺障害 に関する確実な報告は 1988 年の Raidooによるもの で，それによると，実験的に古典的なメンデルソン 症候群を発症させるためには $0.8 \mathrm{ml} \cdot \mathrm{kg}^{-1}$ 以上の胃 液を直接気管内へ注入する必要があった。

現在の誤嶼性肺障害に対する一般的な見解は, 頻 度は $1 \sim 10 / 10,000$ 麻酔症例, 生じる肺障害の程度も おおむね軽度で, 誤曣のリスクファクターは, 肥 満・妊婦・挿管困難症等，マスク換気時に胃膨張を 生じやすい病態と考えられている.

最近, Anesth AnalgのEditorial boad (1998；87) で, Schreiner MSが “Gastric Fluid Volume : Is It Really a Risk Factor for Pulmonary Aspiration ?" というタイトルで誤嚥性肺障害と胃液量の問題を取 り上げている。「健康な小児における胃液量のメディ アンは約 $0.3 \mathrm{~m} l \cdot \mathrm{kg}^{-1}$ (平均は約 $0.4 \mathrm{~m} l \cdot \mathrm{kg}^{-1}$, 最大 $\left.4.5 \mathrm{~m} l \cdot \mathrm{kg}^{-1}\right)$ である。誤嚥の頻度は約 $1 / 3,000$ 麻酔症 例, 誤嶼症例の約 $1 / 3$ が有症状で, ICU 入室が必要 なのは $1 / 12,000$ 麻酔症例，死亡は $1 / 72,000$ 麻酳症例 である」という今までの研究結果のまとめから, (1)胃 液量・胃液 $\mathrm{pH}$ による危険性の判定は間違いで, (2)今後は，危険性を増す「麻酔法や患者の状態」を 探求すべきである，と述べている。胃液から離れた, 視点の変更が必要なのであろう。

\section{参考文献}

1） 仁科かほる, 三川勝也, 志賀真ほか：小児麻酔：クロ ニジン前投薬を中心として．日臨麻会誌 $19 ： 127$ 134, 1999

$$
\begin{array}{ll}
\text { 著者連絡先 } & \text { 前川信博 } \\
\text { 厂 650-0017 } & \text { 神戸市中央区楠町 7-5-2 } \\
& \text { 神戸大学医学部麻酔学教室 }
\end{array}
$$

